\title{
Squamous Cell Carcinoma of the Lung with Osteoclast- Like Giant Cells: A Rare Case
}

\section{Osteoklast Benzeri Dev Hücreler İçeren Akciğerin Skuamöz Hücreli Karsinomu: Nadir Bir Olgu}

\author{
Yetkin AĞAÇKIRAN ${ }^{1}$, Suat GEZER ${ }^{2}$, Göktürk FINDIK ${ }^{3}$, İrfan TAŞTEPE \\ Departments of ${ }^{1}$ Pathology and ${ }^{3}$ Thoracic Surgery, Ataturk Chest Diseases and Chest Surgery Training and Research Hospital, ANKARA, \\ ${ }^{2}$ Thoracic Surgery, Düzce University, Medical School, DUZCE, TURKEY
}

\section{ABSTRACT}

Stromal reactions including benign osteoclast-like giant cells are rarely seen within carcinomas. They are even extremely rare in lung carcinomas.

A 61-year-old male patient who had marked volume loss in the right lung radiologically was admitted. Fiberoptic bronchoscopy was performed, an endobronchial lesion arising from the right upper lobe bronchus and nearly completely obstructing the right main bronchus was detected and multiple biopsies were taken. Histopathological examination of these biopsies confirmed a non-small cell carcinoma with osteoclast-like multinuclear giant cells. A sleeve upper lobectomy was performed through a right thoracotomy. Histopathological examination of the specimen showed "poorly differentiated squamous cell carcinoma and osteoclast-like multinuclear giant cells within". The patient is well and disease-free 42 months after the operation.

There are numerous cases of osteoclast-like giant cells reported within the breast, thyroid, liver, gall bladder, stomach, pancreas, urinary bladder and endometrium but they are very rare within lung carcinomas. A diagnosis of lung carcinoma with osteoclast-like giant cells is very important as it may cause diagnostic confusion with giant cell carcinomas and foreign body type stromal reactions.

Key Words: Lung carcinoma, Squamous cell carcinoma, Giant cells, Immunohistochemistry

\section{INTRODUCTION}

Osteoclast-like giant cells (OLGCs) are generally found within lesions that have an osteogenic component. OLGCs have been described infrequently among malignancies such as malignant neoplasms of breast, thyroid, parotid, ovary, endometrium, stomach, pancreas, colon, kidney, bladder, liver, and gallbladder. Occurrence in the lung is very rare. These tumors may cause considerable diagnostic problems with giant cell carcinomas and foreign body type stromal

Received : 12.06 .2009

Accepted : 04.07.2009
ÖZ

Osteoklast benzeri multinükleer dev hücreler içeren stromal reaksiyonlar karsinomlarda nadir olarak görülür, akciğer karsinomlarında ise daha da nadirdir.

Radyolojik olarak sağ akciğerinde volüm kaybına sebep olan 61 yaşındaki erkek hasta kliniğe kabul edildi. Hastaya yapılan bronkoskopide sağ üst lob bronşundan kaynaklanan ve sağ ana bronşu tama yakın tıkayan endobronşiyal lezyon tespit edildi. Lezyondan multipl biyopsiler alındı. Biyopsi sonucu osteoklast benzeri multinükleer dev hücreler içeren non-small cell karsinom olarak raporladık. Hastaya sağ torakotomi ile sleeve üst lobektomi yapıldı. Postoperatif tanıyı osteoklast benzeri multinükleer dev hücreler içeren az diferansiye skuamöz hücreli karsinoma olarak raporladık. Hasta 42. ayında ve sorunsuz olarak takip edilmektedir.

Osteoklast benzeri multinükleer dev hücreler içeren karsinomlar meme, tiroid, karaciğer, safra kesesi, mide, pankreas, prostat ve endometriumda çok sayıda raporlanmıştır, ancak akciğer karsinomlarında oldukça azsayıdadır. Osteoklast benzerimultinükleer dev hücreler içeren akciğer karsinomlarının ayırıcı tanısı önemlidir çünkü bu karsinomlar yabancı cisim tipi stromal reaksiyonlar ve dev hücreli karsinomlarla karışabilir.

Anahtar Sözcükler: Akciğer karsinomu, Skuamöz hücreli karsinoma, Dev hücreler, İmmünohistokimya

reactions. Based on this limited experience, lung carcinoma with OLGCs may represent a distinct clinicopathological entity. We present a case of lung carcinoma with OLGCs who is alive and well for 42 months after resection.

\section{CASE REPORT}

A 61-year-old male patient with a complaint of shortness of breath was referred to our clinic after detection of a marked volume loss in the right lung on chest radiography

Correspondence: Yetkin AĞAÇKIRAN

Department of Pathology, Atatürk Chest Diseases and Chest Surgery

Training and Research Hospital, ANKARA, TURKEY

E-mail: yagackiran@hotmail.com Phone: +90 3123154733 
and computed tomography (Figure 1A,B). Fiberoptic bronchoscopy showed an endobronchial lesion arising from the right upper lobe bronchus and nearly completely obstructing the right main bronchus. Multiple biopsies were taken. Histopathological examination of these biopsies confirmed a non-small cell carcinoma with OLGCs and a sleeve upper lobectomy with right thoracotomy was performed. Postoperative staging was accepted as stage I. During the postoperative period, the patient had a prolonged air leak and empyema. The air leak ceased and empyema was resolved after proper treatments and the patient was discharged on the postoperative 45th day. We did not observe any complications during the follow-up period of 42 months and the patient is alive and disease free.

Macroscopic examination of the $15 \times 8 \times 5 \mathrm{~cm}$ sleeve upper lobectomy material displayed an endobronchial tumor $2.4 \mathrm{~cm}$ in diameter in the lumen of upper lobe bronchus infiltrating the bronchial wall. Histopathological examination of the tumor showed "poorly differentiated squamous cell carcinoma and osteoclast-like multinuclear giant cells within" (Figure 2). Immunohistochemical studies demonstrated expression of high molecular weight keratin, cytokeratin5/6, CEA, EMA and pancytokeratin in tumor cells. While OLGCs showed expression of vimentin and CD68, staining with CEA, EMA, pancytokeratin, CD45, actin, desmin, S-100 protein or calretinin were not observed. We found marked angiogenesis in the stroma around the OLGCs. The vascular proliferation was highligtened by

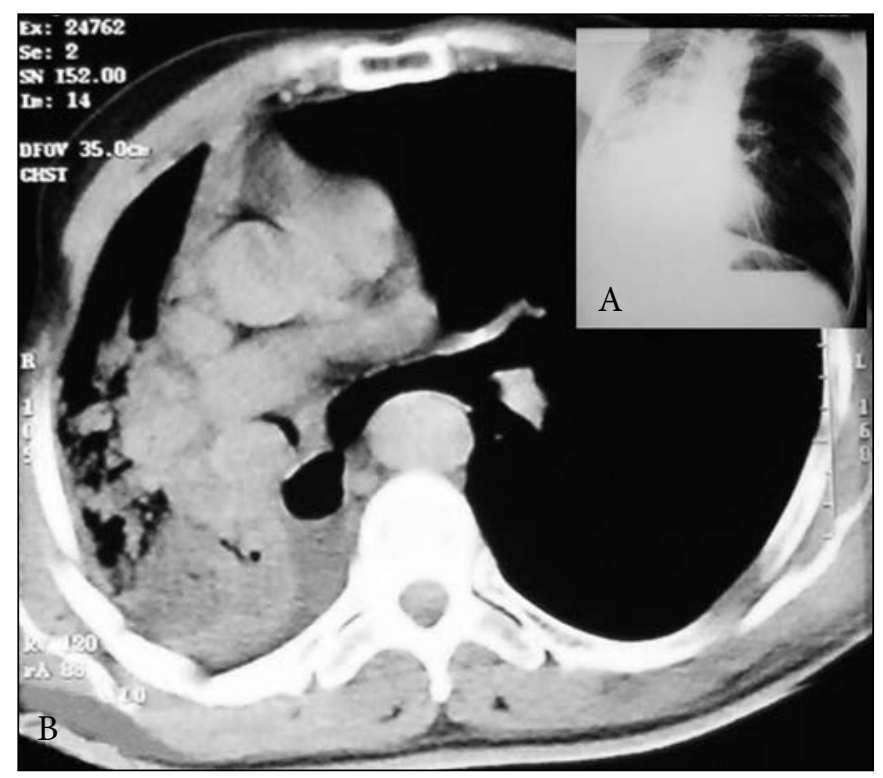

Figure 1: A) Chest x-ray: marked volume loss in the right lung on chest radiography. B) Computed tomography of thorax: an endobronchial lesion arising from right upper lobe bronchus. strong immunohistochemical expression with CD34 and CD31 (Figure 3).

\section{DISCUSSION}

Love et al. reported the first case of lung cancer containing OLGCs in 1983. The tumor was sarcomatoid squamous cell carcinoma. In their paper, they underlined that this type of tumor may cause diagnostic problems (1). The second case of the literature was reported by Nakahashi et al. in 1987. The tumor was undifferentiated carcinoma consisting of adenocarcinoma foci in small areas with OLGCs. They discussed the histogenesis of OLGCs in their paper (2). Later, Leung et al. reported a case of large cell carcinoma with OLGCs in 1998. They underlined in their paper that while the diagnosis of these tumors is generally clear in resection specimens, they may cause problems in preoperative

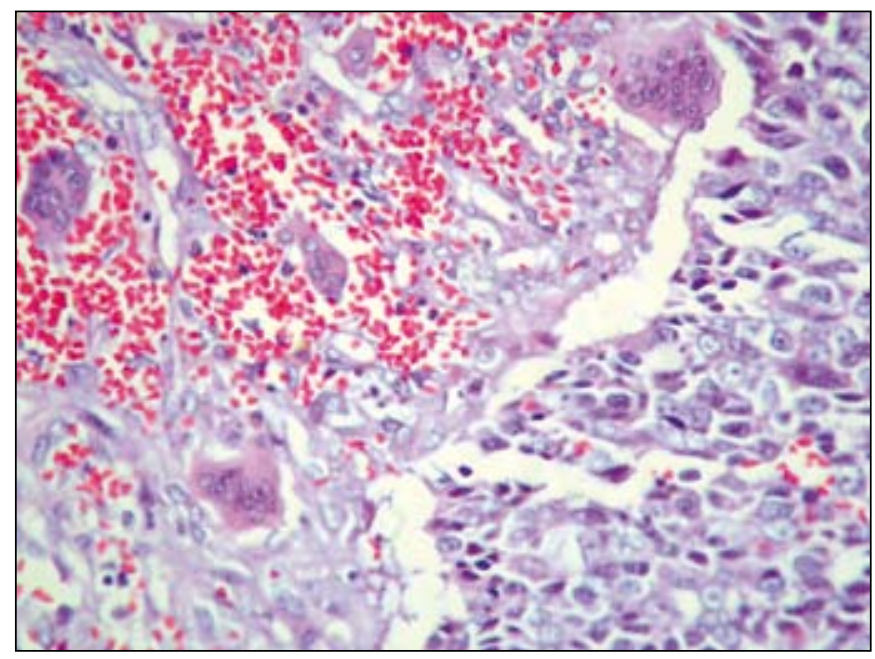

Figure 2: Squamous cell carcinoma of lung with osteoclast like giant cells in the stromal (H\&E, $\mathrm{x} 400)$.

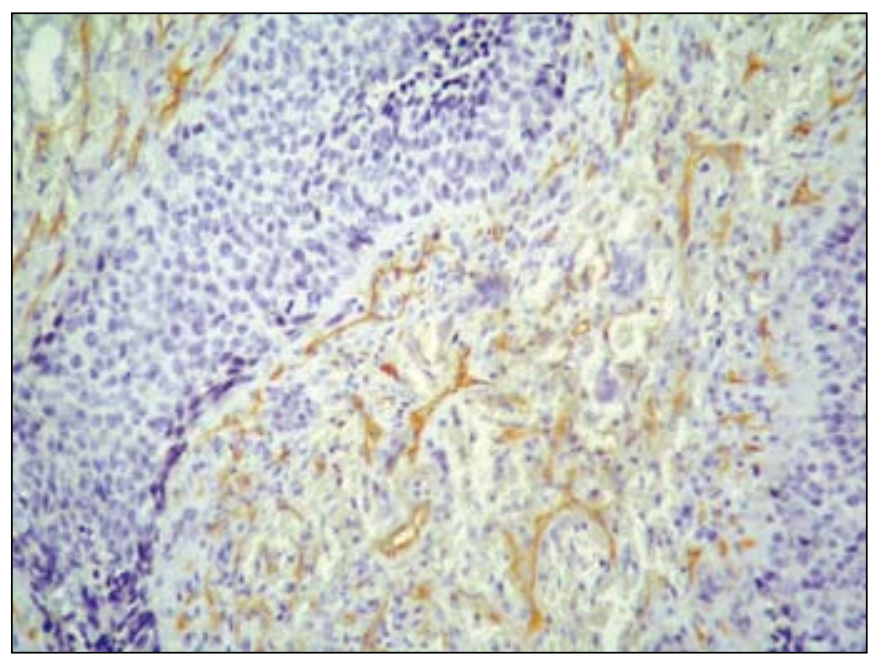

Figure 3: Marked angiogenesis demonstrated with CD31 among osteoclast like giant cells (x200). 
differential diagnosis. They said that carcinomas with OLGCs should be distinguished from giant cell carcinoma where the giant cells are bizarre, malignant-looking and epithelial in nature (3).

We also think that some diagnostic problems may be experienced with those tumors. Foreign body type stromal reactions also contain giant cells. The differential diagnosis is usually obvious in resected specimens. However, small biopsies may be difficult to interpret and fine needle aspirates may be confusing. Immunohistochemistry may be helpful in these circumstances. We performed immunohistochemistry after the diagnosis of squamous cell carcinoma and observed expression with epithelial markers in tumor cells and strong positivity with histiocytic markers in OLGCs.

The largest series was from Bocklage et al. in 1998 consisting 3 carcinoma cases. They reported 1 adenocarcinoma and 2 sarcomatoid carcinomas and discussed the host reaction and possible mechanisms that may stimulate OLGC response (4). They said that osteoclastic differentiation from monocyte/macrophage bone marrow precursor cells and peripheral blood monocytes is a complex process that involves a host of soluble mediators as well as cell contact with osteoblasts.

Agnantis et al. discussed the angiogenesis in those tumors and underlined that the observation that the giant cells generally occurred in areas of prominent angiogenesis suggests that angiogenesis may be induced by some chemical substancs produced by the tumor cells (5). In our case, we observed marked angiogenesis in the stroma surrounding OCLGCs too. Strong immunochemical staining with CD31 and CD34 showed prominent vascular proliferation.

In Leung and Morava-Protzner's study, immunohistochemical stains demonstrated that the giant cells were of monocytic/histiocytic origin probably representing a distinctive host response to the tumor (3). Our immunohistochemistry study results, including strong positivity with CD68 and negativity with epithelial markers also confirmed that OLGCs were of histiocytic origin.
Our patient is well and disease free 42 months after the resection. Although it is difficult to comment on the prognosis of lung carcinomas with OLGCs for now since they are very rare, it is said that those cells indicate good prognostic factor in other system malignancies with similar findings (6-8). Further studies are needed to comment on the prognosis of lung carcinomas with OLGCs.

This is the seventh published report of lung carcinoma with osteoclast-like giant cells as far as we know according to our research. Based on this limited experience, lung carcinoma with OLGCs may represent a distinct clinicopathological entity with a more favorable prognosis. Careful microscopic examination and immunohistochemistry may be helpful in the differential diagnosis.

\section{REFERENCES}

1. Love GL, Daroca PJ Jr: Bronchogenic sarcomatoid squamous cell carcinoma with osteoclast-like giant cells. Hum Pathol 1983, 14:1004-1006

2. Nakahashi H, Tsuneyoshi M, Ishida T, Minagawa S, Owaki Y, Momii S, Eimoto T: Undifferentiated carcinoma of the lung with osteoclast-like giant cells. Jpn J Surg 1987, 17:199-202

3. Leung CS, Morava-Protzner I: Large cell carcinoma of lung with osteoclast-like giant cells. Histopathology 1998, 32:482-484

4. Bocklage TJ, Dail D, Colby TV: Primary lung tumors infiltrated by osteoclast-like giant cells. Ann Diagn Pathol 1998, 2:229-240

5. Agnantis NT, Rosen PP: Mammary carcinoma with osteoclastlike giant cells. A study of eight cases with follow-up data. Am J Clin Pathol 1979, 72:383-389

6. Tezuka K, Yamakawa M, Jingu A, Ikeda Y, Kimura W: An unusual case of undifferentiated carcinoma in situ with osteoclastlike giant cells of the pancreas. Pancreas 2006, 33:304-310

7. Berzal Cantalejo F, Sabater Marco V, Alonso Hernández S, Jiménez Peña R, Martorell Cebollada MA: Syncytial giant cell component. Review of 55 renal cell carcinomas. Histol Histopathol 2004, 19:113-118

8. Akatsu T, Kameyama K, Kawachi S, Tanabe M, Aiura K, Wakabayashi G, Ueda M, Shimazu M, Kitajima M: Gallbladder carcinoma with osteoclast-like giant cells. J Gastroenterol 2006, $41: 83$ 